\title{
Yemen field epidemiology training programme: a tool for strengthening the public health workforce
}

Abdulwahed Al Serouri, ${ }^{1}$ Aisha Jumaan ${ }^{2}$ and Abdulhakem Alkohlani ${ }^{1}$

${ }^{1} Y e m e n$ Field Epidemiology Training Programme, Ministry of Public Health and Population, Sana'a, Yemen (correspondence to: Abdulwahed Al Serouri: A_alserouri@yahoo.com). ${ }^{2}$ Independent Consultant, Seattle, Washington, United States of America.

\begin{abstract}
Background: The shortage of skilled public health workers, especially epidemiologists, remains an important challenge for building effective public health systems in many low-income countries, including Yemen. To address this need, in 2011 the Ministry of Public Health and Population established the Yemen Field Epidemiology Training Programme (Y-FETP).

Aims: To describe the Y-FETP and its strengths and challenges in addressing Yemen's National Health System (NHS) needs.

Methods: We describe the structure and functions of the Y-FETPs and analyse the achievements and challenges of the first 7 years of programme implementation as they relate to the NHS.

Results: The Y-FETP is a postgraduate competency-based training with the objective of strengthening capacity in field epidemiology so that events of public health importance can be detected and investigated in a timely and effective manner. Since its establishment, the Y-FETP has successfully trained 30 health professionals in advanced field epidemiology. Furthermore, trainees investigated over 100 outbreaks, analysed and evaluated 95 surveillance systems, conducted 30 planned studies and presented 70 oral and poster presentations at national and international conferences. The main challenges are low retention of graduates by the NHS and financial unsustainability.

Conclusions: The Y-FETP has strengthened the capacity of the Yemen health workforce and has been instrumental in supporting the NHS, especially during the war and the current crisis and health emergency as the security situation deteriorated and access to outside experts becomes limited. The programme provides a practical example of health systems strengthening through health workforce capacity development that can be replicated in countries with similar health workforce capacity challenges.
\end{abstract}

Keywords: field epidemiology training, Yemen, health workforce, health systems strengthening

Citation: Al Serouri A; Jumaan A; Alkohlani A. Yemen field epidemiology training programme: a tool for strengthening the public health workforce. East Mediterr Health J. 2018;24(9):905-913. https://doi.org/10.26719/2018.24.9.905

Received: 02/10/17; accepted: 22/03/18

Copyright $\odot$ World Health Organization (WHO) 2018. Some rights reserved.This work is available under the CC BY-NC-SA 3.0 IGO license (https:// creativecommons.org/licenses/by-nc-sa/3.o/igo).

\section{Introduction}

The shortage of skilled public health workers, especially epidemiologists, remains an important challenge for building effective public health systems in many developing countries (1). Hence, the World Health Organization (WHO) has included health workforce as one of the key building blocks for strengthening health systems (2). Yemen has been identified as one of 7 countries in the Eastern Mediterranean Region facing public health crises with an alarming shortage of curative and preventive health care workers (3).

The 2006 WHO Yemen Health Systems Profile shows there is a lack of the basic data, e.g. disease prevalence, regional variation and epidemiological trends, needed for planning (4). It also identifies delayed response to outbreaks and epidemics as a major constraint that the national health system is facing and constitutes a priority in reforming the health sector (4). Therefore, in Yemen's third Five-Year (2006-2010) Development Plan, an objective was included "to combat epidemics, and endemic and infectious diseases and reduce morbidity and mortality rates" through enhancing health and demographic and environmental education (5). To address these needs, the Ministry of Public Health and Population established the Yemen Field Epidemiology Training Programme (Y-FETP) in 2011. This programme is a variant of the international Field Epidemiology Training Programme (FETP) model that was built on the Centers for Disease Control and Prevention (CDC) Epidemic Intelligence Service established in $1951(6,7)$. The Y-FETP was established as a partnership between the Ministry of Public Health and Population, CDC in Atlanta, Georgia, United States, and WHO in Yemen. Further support was received from the Training Programme in Epidemiology and Public Health Interventions Network (TEPHINET) and the Eastern Mediterranean Public Health Network (EMPHNET). The Y-FETP is a 2-year training programme based on the philosophy of "learning while doing" (8). This paper describes the Y-FETP and its successes to date.

The Yemen Field Epidemiology Training Programme

\section{Goals of the programme}

The training objectives of the Y-FETP include: build sus- 
tainable capacity within the Ministry of Public Health and Population to detect, investigate and respond to outbreaks; analyse and evaluate disease surveillance systems; use population-based health data to estimate the burden of injuries and communicable and noncommunicable diseases; evaluate the impact of health-related interventions; and use data for policy-making and decision-making (8). The programme will also support the Ministry of Public Health and Population in meeting the Global Health Security Agenda target of having one trained field epidemiologist per 200000 population by 2025 .

\section{Training curriculum and schedule}

The Y-FETP is housed in the Disease Surveillance and Control Directorate in the Curative Services and Primary Health Sector of the Ministry of Public Health and Population. The integration of Y-FETP into the ministry ensures that residents are equipped with the necessary skills to respond to Yemen's needs. The Y-FETP curriculum (8) was adapted from CDC's core FETP curriculum $(7,9)$, which focuses on preparing residents with the necessary skills to address countries' acute health priorities. Residents spend at least $75 \%$ of their time in the field gaining hands-on experience (8).

In the first year, Y-FETP residents have both didactic and field trainings; typically, they participate in multiple trainings sessions throughout the year. First, they participate in a 4-week introductory course covering the basic concepts of epidemiology, biostatistics, surveillance and outbreak investigation as well as training on EpiInfo software, focusing on designing questionnaires and entering and analysing data. Then, residents are hosted by surveillance programmes determined by the priorities of the Ministry of Public Health and Population, (Table 1) and the availability of applied learning opportunities and qualified site supervisors. Programmes' supervisors are Ministry of Public Health and Population staff with background in epidemiology/public health; they attend a workshop on the Y-FETP and supervision and mentorship skills before residents are placed in their programmes. They are also invited to attend trainings organized by Y-FETP e.g. EpiInfo statistical software, and outbreak investigation. Supervisors participate in quarterly mentors' workshops, and in co-authoring publications.

During the second year, residents participate in three didactic workshops focusing on advanced epidemiological methods, advance EpiInfo software, and protocol writing, and are placed at technical units in the governorates, national programmes and directorates. They analyse data to document burden of diseases and evaluate data collection systems to recommend appropriate actions for improvement (8).

Residents are placed in programmes early so that they can immediately apply their newly acquired skills in responding to Yemen's public health priorities. During their training, Y-FETP residents conduct field activities relevant to their host programmes at national and regional levels, including outbreak investigations, campaigns and surveys (8). They perform activities

\begin{tabular}{|c|c|}
\hline Training programme & Placement programme \\
\hline $\begin{array}{l}\text { Disease Surveillance and Control General } \\
\text { Directorate }\end{array}$ & $\begin{array}{l}\text { National Malaria Control Programme } \\
\text { National Tuberculosis Control Programme } \\
\text { National AIDS Programme } \\
\text { National Schistosomiasis Control Programme } \\
\text { Electronic Early Disease Warning System } \\
\text { Integrated Disease Surveillance } \\
\text { Laboratory Based Surveillance } \\
\text { Dengue Surveillance Programme } \\
\text { Leishmania Surveillance Programme } \\
\text { Influenza Surveillance Programme } \\
\text { Blindness Control Programme } \\
\text { Rabies Control Programme } \\
\text { Soil Transmitted Helminths Control Programme } \\
\text { Tobacco Control Programme }\end{array}$ \\
\hline General Directorate of Family Health & $\begin{array}{l}\text { Expanded Programme for Immunization } \\
\text { Nutrition Directorate } \\
\text { Integrated Management of Child Illness } \\
\text { School Health Directorate }\end{array}$ \\
\hline National Central Public Health Laboratories & $\begin{array}{l}\text { Communicable Disease Directorate } \\
\text { Noncommunicable Disease Directorate }\end{array}$ \\
\hline General Directorate of Animal Health & $\begin{array}{l}\text { Central Veterinary Laboratory } \\
\text { Epidemiology and Surveillance Directorate }\end{array}$ \\
\hline Other directorates/programmes & $\begin{array}{l}\text { National Oncology Centre } \\
\text { Noncommunicable Disease Directorate } \\
\text { Emergency and Ambulance Directorate } \\
\text { National Blood Transfusion Centre } \\
\text { National Camps Programme }\end{array}$ \\
\hline
\end{tabular}


that provide direct service to the host programmes by completing the following required core competencies and deliverables for graduation (8).

- Analyse surveillance data or programmes/directorates data to document the burden of disease and recommend appropriate actions in brief public health reports for policy- and decision-makers

- Evaluate strengths and challenges of surveillance systems or programmes/directorates data systems and make appropriate recommendations.

- Design and implement epidemiological study on priority public health topics in the particular site, analyse data and draft a manuscript for publication.

- Conduct outbreak investigations and recommend control and prevention measures.

- Submit at least 1 abstract and present at a conference as oral or poster.

A team of programmes' supervisors provides support to Y-FETP residents; they are guided primarily by the Y-FETP director and are supported by the Y-FETP technical advisor, consultant epidemiologist and junior epidemiologist (10). Supervisors provide daily support to Y-FETP residents towards fulfilling graduation requirement and providing evaluation of their progress. When required, supervisors and Y-FETP technical staff accompany the residents on relevant outbreak investigations and field activities. Y-FETP Management staff visit the residents at hosting programmes and institutions monthly and hold quarterly meetings with programmes directors and supervisors to discuss the progress of the residents and address any relevant issues.

During the 2-year training, residents provide direct service to the Ministry of Public Health and Population, including training and supervising health workers (e.g. during immunization campaigns, surveys) and participating in special trainings (e.g. International Health Regulations, biosafety and biosecurity, strategic planning, leadership). The residents are also required to actively participate in the bi-weekly Y-FETP meetings and present their work for critique by their peers, technical leadership within the Ministry of Public Health and Population and programme staff.

Upon completion of the requirements, graduating Y-FETP residents receive a certificate from CDC that is co-signed by the Yemen Minister of Public Health and Population (8). The graduates are recognized by the Ministry of Public Health and Population as specialists in field epidemiology and are given priority when recruiting for higher rank positions. Several were tasked with directing national programmes. The programme is currently in discussion with the Ministry of Higher Education to recognize the Y-FETP certificate as a professional master's degree.

\section{Major accomplishments}

Since Y-FETP was established in 2011, 4 cohorts $(n=46)$ of residents joined the programme; $76 \%$ were from various governorates. Of 34 residents enrolled in the first three cohorts, $30(88 \%)$ graduated; Most residents are physicians $(68 \%)$, the others are health professionals (e.g. laboratory, pharmacy, nursing) who hold a master's degree or diploma after achieving a university first degree. One veterinarian was enrolled in the first cohort to support One Health.

The following four domains are supported by the Y-FETP.

\section{- Improve surveillance systems}

Although surveillance data are collected by numerous programmes, these data were not analysed, interpreted or disseminated in a timely manner to guide public health decision-making or action. Therefore, each Y-FETP resident is required to conduct an analysis and write a report of at least one surveillance system, using case-based or aggregate data, on a disease or an event. This is done in consultation with programme managers to ensure that the analysis focusses on priority issues. The Y-FETP technical staff participate in the meetings to identify the topic/question to be addressed for analysis, discuss the findings and assist the residents to develop appropriate recommendations. These efforts ensure scientific integrity and foster programme ownership and collaboration. To date, Y-FETP residents have completed 60 surveillance analyses (Table 2). They also supported 9 less-established surveillance programmes (e.g. leishmaniasis, schistosomiasis) to improve the quality of the data by designing automated databases using EpiInfo for data entry and analysis (11).

The surveillance system analyses provide an opportunity for the residents to identify potential challenges that are used to guide the evaluation aspects. Residents use the updated CDC Guidelines for Evaluating Public Health Surveillance Systems (12), completing 35 evaluations (Table 3). These evaluations ensure that gaps or challenges of public health importance are monitored efficiently and effectively. They focus on system performance to meet stated objectives, and involve assessment of the system attributes, including simplicity, flexibility, data quality, acceptability, sensitivity, positive predictive values, representativeness, timeliness and stability.

Since residents are placed in Ministry of Public Health and Population priority programmes, the recommendations based on the surveillance systems analyses and evaluations are taken seriously by the Ministry and the programmes. The results provide information that promotes the optimal use of health resources and ensure that the systems operate effectively. The recommendations provide practical guidance to ensure that the system is meeting its stated objectives and to improve quality and efficiency. Although, it may be too soon to show the impact of the surveillance analyses and evaluations, Y-FETP plans 


\begin{tabular}{|c|c|c|}
\hline Cohort & Title & Presented at \\
\hline \multirow[t]{3}{*}{ First } & Traumatic injection neuropathy surveillance, Yemen, 1998-2012 & \multirow{3}{*}{$\begin{array}{l}\text { First Arab World Public Health Conference, Dubai, } \\
\text { United Arab Emirates, 4-6 April } 2013\end{array}$} \\
\hline & Rubella surveillance system data analysis, 2008-2011 & \\
\hline & $\begin{array}{l}\text { Epidemiological characteristics of human rabies cases in Sana'a city, } \\
2011\end{array}$ & \\
\hline \multirow[t]{4}{*}{ Second } & $\begin{array}{l}\text { Analysis of } 4 \text { injury-reporting data sets at the Ministry of Public } \\
\text { Health and Ministry of Interior, Yemen, } 2012\end{array}$ & $\begin{array}{l}\text { 4th EMPHNET Regional Conference, Aqaba, Jordan, } 28 \\
\text { September-1 October } 2015\end{array}$ \\
\hline & $\begin{array}{l}\text { Antibiotic resistance profiling of blood stream bacterial infection, } \\
\text { National Center of Public Health Laboratories, Yemen, 2012-2014 }\end{array}$ & \multirow{2}{*}{$\begin{array}{l}\text { 8th TEPHINET Global Conference, Mexico City, Mexico, } \\
\text { 7-11 September } 2015\end{array}$} \\
\hline & $\begin{array}{l}\text { Epidemiology of soil transmitted helminths and schistosomiasis in } \\
\text { schoolchildren, Yemen, } 2014\end{array}$ & \\
\hline & $\begin{array}{l}\text { Severe acute respiratory infection surveillance analysis, Yemen, } \\
2011-2014\end{array}$ & $\begin{array}{l}\text { 17th International Conference of Infectious Diseases, } \\
\text { Hyderabad, India, 1-4 March } 2016\end{array}$ \\
\hline \multirow[t]{3}{*}{ Third } & $\begin{array}{l}\text { Analysis of tuberculosis drug resistance cases enrolled for treatment, } \\
2013-2016\end{array}$ & \multirow{3}{*}{$\begin{array}{l}\text { To be submitted to the 6th EMPHNET Regional } \\
\text { Conference, Amman, Jordan, } 27 \text { and } 29 \text { March } 2018\end{array}$} \\
\hline & Malaria surveillance system analysis, Yemen, 2011-2015 & \\
\hline & $\begin{array}{l}\text { Descriptive analysis for dengue fever and malaria in electronic } \\
\text { disease early warning system, Yemen (2015-2016) }\end{array}$ & \\
\hline
\end{tabular}

future qualitative and quantitative research to assess improvements in performance.

\section{- Improve outbreak investigation and response}

The Y-FETP residents and graduates actively participated in investigating and responding to more than 100 outbreaks such as cholera, dengue, rabies, Neisseria meningitis, measles, pertussis, hepatitis, food poisoning, etc. (Table 4). Residents responded to suspected outbreaks early and used high standards during investigations; they also developed recommendations for rapid containment and prevention of future outbreaks. Moreover, they investigated and reported the first occurrence in Yemen of outbreaks of Chikungunya virus, West Nile virus, and Middle East respiratory syndrome coronavirus (MERS-CoV).

Residents are currently participating in the investigation of the "world's worst cholera outbreak" (27 April-10 December 2017), which has led to a cumulative total of 983333 suspected cases and 2215 deaths (13). The Ministry of Public Health and Population selected Y-FETP 3rd cohort residents as cholera control coordinators in the 10 districts with the highest caseload to provide technical guidance to the district

\begin{tabular}{|c|c|c|}
\hline Cohort & Title & Presented at \\
\hline \multirow[t]{4}{*}{ First } & $\begin{array}{l}\text { Evaluation of Malaria surveillance system in Al Dhale Governorate } \\
\text { Yemen, March } 2011\end{array}$ & $\begin{array}{l}\text { 2nd EMPHNET and 5th TEPHNET Regional Conference, } \\
\text { 6-9 December 2011, Sharm Al Sheikh, Egypt }\end{array}$ \\
\hline & $\begin{array}{l}\text { Evaluation of acute flaccid paralysis surveillance system in Ibb } \\
\text { Governorate, Yemen, } 2013\end{array}$ & \multirow{2}{*}{$\begin{array}{l}\text { 3rd EMPHNET Regional Conference, Marrakesh, } \\
\text { Morocco, 4-7 December } 2013\end{array}$} \\
\hline & $\begin{array}{l}\text { Evaluation of acute flaccid paralysis surveillance system in the Costal } \\
\text { Hadramaut Governorate, Yemen, } 2013\end{array}$ & \\
\hline & $\begin{array}{l}\text { Evaluation of acute flaccid paralysis surveillance system in the } \\
\text { Hodeidah Costal Governorate, Yemen, } 2014\end{array}$ & $\begin{array}{l}\text { 4th EMPHNET Regional Conference, Aqaba, Jordan, } 28 \\
\text { September-1 October } 2015\end{array}$ \\
\hline \multirow[t]{3}{*}{ Second } & $\begin{array}{l}\text { Evaluation of the electronic diseases early warning system, Sana'a, } \\
\text { Yemen, } 2014\end{array}$ & $\begin{array}{l}\text { 4th EMPHNET Regional Conference, Aqaba, Jordan, } 28 \\
\text { September-1 October } 2015\end{array}$ \\
\hline & $\begin{array}{l}\text { Measles surveillance system evaluation, Amran Governorate, Yemen, } \\
2014\end{array}$ & \multirow{2}{*}{$\begin{array}{l}\text { 8th TEPHINET Global Conference, Mexico City, Mexico, } \\
\text { 7-11 September } 2015\end{array}$} \\
\hline & $\begin{array}{l}\text { Evaluation of the Integrated Malaria Surveillance System, Sana'a, } \\
\text { Yemen, } 2014\end{array}$ & \\
\hline \multirow[t]{3}{*}{ Third } & $\begin{array}{l}\text { Evaluation of Acute Flaccid Paralysis (AFP) Surveillance System in } \\
\text { Yemen, 2010-2015; using secondary data }\end{array}$ & $\begin{array}{l}\text { 9th TEPHINET Global Scientific Conference Chiang } \\
\text { Mai, Thailand 7-11 August } 2017\end{array}$ \\
\hline & $\begin{array}{l}\text { Evaluation of multi-drug resistant Tuberculosis surveillance in } \\
\text { Yemen } 2016\end{array}$ & \multirow{2}{*}{$\begin{array}{l}\text { To be submitted to the 6th EMPHNET Regional } \\
\text { Conference, Amman, Jordan, } 27 \text { and } 29 \text { March } 2018\end{array}$} \\
\hline & $\begin{array}{l}\text { Evaluation of the } 2 \text { malaria surveillance systems in Sana'a, Yemen, } \\
2016\end{array}$ & \\
\hline
\end{tabular}




\begin{tabular}{|c|c|c|}
\hline Cohort & Title & Presented at \\
\hline \multirow[t]{4}{*}{ First } & Dengue or Chikungynya fever outbreak? & $\begin{array}{l}\text { First Arab World Public Health Conference, Dubai, United } \\
\text { Arab Emirates, 4-6 April 2013, }\end{array}$ \\
\hline & $\begin{array}{l}\text { Measles outbreak with high fatality at Qufl Shamr district, } \\
\text { Hajja Governorate, Yemen, } 2012\end{array}$ & \multirow{2}{*}{$\begin{array}{l}\text { 3rd EMPHNET Regional Conference, Marrakesh, } \\
\text { Morocco, 4-7 December } 2013\end{array}$} \\
\hline & $\begin{array}{l}\text { An outbreak of acute gastroenteritis associated with bottled } \\
\text { water in internally displaced persons, Yemen, } 2013\end{array}$ & \\
\hline & Mixed outbreak of dengue and West Nile virus, Yemen, 2013 & 16th ICID, Cape Town, South Africa, 2-5 April 2014 \\
\hline \multirow[t]{3}{*}{ Second } & $\begin{array}{l}\text { H1N1 outbreak in Hareb Baihaan district, Mareb, Yemen: the } \\
\text { challenges and lessons learned, August } 2014\end{array}$ & $\begin{array}{l}\text { Yemeni International Congress on Infectious Diseases, } \\
\text { University of Science \& Technology Hospital, Sana'a, } \\
\text { Yemen, Sana'a, Yemen, 16-18 December } 2014\end{array}$ \\
\hline & $\begin{array}{l}\text { Fauvism outbreak after charitable food distribution in } \mathrm{Al} \\
\text { Dhalae Governorate, Yemen, April } 2014\end{array}$ & $\begin{array}{l}\text { 8th TEPHINET Global Conference, Mexico City, Mexico, } \\
\text { 7-11 September } 2015\end{array}$ \\
\hline & $\begin{array}{l}\text { Explosive measles outbreak among unvaccinated children } \\
\text { due to parent refusal, in Al Jawf Governorate, Yemen, March } \\
2015\end{array}$ & $\begin{array}{l}\text { 4th EMPHNET Regional Conference, Aqaba, Jordan, } 28 \\
\text { September-1 October } 2015\end{array}$ \\
\hline \multirow[t]{3}{*}{ Third } & $\begin{array}{l}\text { Outbreak investigation of cutaneous leishmaniasis in Yanaha } \\
\text { village, Amran Governorate, Yemen, } 2016\end{array}$ & $\begin{array}{l}\text { 9th TEPHINET Global Scientific Conference Chiang Mai, } \\
\text { Thailand 7-11 August } 2017\end{array}$ \\
\hline & $\begin{array}{l}\text { Impact of intervention on dengue outbreak in Baihan district, } \\
\text { Shabwah, Yemen, } 2016\end{array}$ & \multirow{2}{*}{$\begin{array}{l}\text { To be submitted to the 6th EMPHNET Regional } \\
\text { Conference, Amman, Jordan, } 27 \text { and } 29 \text { March } 2018\end{array}$} \\
\hline & $\begin{array}{l}\text { Cholera outbreak in Heran area, Dhamar Governorate, } \\
\text { Yemen, January } 2017\end{array}$ & \\
\hline
\end{tabular}

health teams, support microplanning and evaluate the cholera response activities $(11,14)$.

\section{- Conduct public health operations research on priority topics}

Residents on the programme used sound epidemiologic methods to conduct studies that improve public health programme delivery; they worked closely with the Ministry of Public Health and Population to identify research priorities that highlight health system challenges and help to understand the health problems. Residents used descriptive and analytical designs to identify prevalence and risk factors for communicable and noncommunicable diseases and to investigate health service delivery problems (Table 5). They implemented 30 studies, analysed and interpreted data, made recommendations and produced written reports.

\section{- Disseminate and use public health information}

The Y-FETP was designed to develop the foundation for using epidemiological data for decision-making and to disseminate findings and best practices. The programme conducted more than 30 dissemination workshops and meetings to share findings from the surveillance data analyses and evaluations. Furthermore, the programme conducted 9 dissemination workshops to share the findings from planned studies relevant to the Ministry of Public Health and Population programmes and decision-makers at central and governorate level. Some of these workshops were headed by the Minister of Public Health and Population or his deputies. Similarly, after each outbreak investigation, Y-FETP residents and graduates met with relevant stakeholders at the local level to share preliminary findings and recommendations. The teams also presented and discussed the findings with their colleagues and key Ministry of Public Health and Population officials during the biweekly Y-FETP residents' meeting.

Since its establishment, Y-FETP has presented 46 oral and 24 poster presentations in international, regional and national conferences (Tables 2-5), covering outbreak investigations, surveillance analyses, surveillance evaluations and epidemiological studies. In addition, six articles were published (14-19), one is accepted (20), and four are under review in peer-reviewed journals. Furthermore, Y-FETP conducted the First and Second National Yemen Field Epidemiology Training Programme Conferences in February 2014 and February 2016, with participation of more than 300 public health professionals from the central and governorate levels as well as partners such as WHO, UNICEF, EMPHNET and regional FETP country programmes $(21,22)$.

Finally, Y-FETP activities and achievements are published on a bilingual (Arabic/English) Y-FETP website (http://www.yfetp.com) that was launched in January 2016. Bilingual quarterly reports are also posted on the website. This website presents a forum for the epidemiology/public health community in Yemen to learn about updated Y-FETP public health activities. The website will also strengthen communication with other FETP programmes in the Region and internationally and foster experience-sharing to improve performance.

\section{Challenges}

As a new training programme in Yemen, Y-FETP faces several important challenges, of which the following three need to be addressed promptly in order to achieve the main objective, strengthening the national health system. 


\begin{tabular}{|c|c|c|}
\hline Cohort & Title & Presented at \\
\hline \multirow[t]{4}{*}{ First } & $\begin{array}{l}\text { Immunization status of children aged } 12-23 \text { months and factors } \\
\text { affecting it in rural districts of Alhesen and Nehem, Sana'a Governorate, } \\
2013\end{array}$ & \multirow{4}{*}{$\begin{array}{l}\text { 4th EMPHNET Regional Conference, Aqaba, } \\
\text { Jordan, } 28 \text { September-1 October } 2015\end{array}$} \\
\hline & $\begin{array}{l}\text { Factors associated with nonvaccination among children aged } 12-23 \\
\text { months living in the Ateq capital city, Shabwa Governorate, } 2013\end{array}$ & \\
\hline & $\begin{array}{l}\text { Unintentional injuries among grade 9-12 school students in Sana'a City, } \\
\text { Yemen, } 2012\end{array}$ & \\
\hline & $\begin{array}{l}\text { Knowledge, attitudes and practices relating to cholera among residents } \\
\text { of cholera prone and nonprone areas, Abyan, Yemen, } 2014\end{array}$ & \\
\hline \multirow[t]{6}{*}{ Second } & Burden of road traffic injuries (RTIs) in Sana'a city, Yemen, 2015 & \multirow{6}{*}{$\begin{array}{l}\text { 5th EMPHNET Regional Conference, } \\
\text { Marrakesh, Morocco, 6-8 December } 2016\end{array}$} \\
\hline & Risk factors for breast cancer in Hadramout Al Wadi, Yemen, 2011-2015 & \\
\hline & $\begin{array}{l}\text { Impact of health education on knowledge, attitude and preventive } \\
\text { practices among parents towards dengue fever at Gheel Bawazeer, } \\
\text { Hadhramout, Yemen, } 2016\end{array}$ & \\
\hline & $\begin{array}{l}\text { Default risk factors of severe acute malnourished children from } \\
\text { outpatient therapeutic centres, Sana'a City, Yemen, } 2015\end{array}$ & \\
\hline & $\begin{array}{l}\text { Risk factors of end-stage renal failure among haemodialysis patients in } \\
\text { Algomhory Hospital, Sa'adah Governorate, Yemen, } 2016\end{array}$ & \\
\hline & $\begin{array}{l}\text { Occupational exposure to needle stick injuries and hepatitis B } \\
\text { vaccination coverage among clinical laboratory staff, Sana'a City, } \\
\text { Yemen, } 2015\end{array}$ & \\
\hline
\end{tabular}

\section{- Low retention by health system}

- National and international migration of health professionals from the public health system has become a major concern which hinders improvement of the quality of the health system in Yemen (23). According to the Y-FETP field-book (8), it is important that the Ministry of Public Health and Population has a clear career and committed path for all Y-FETP graduates. It is envisaged that Y-FETP graduates would work as field epidemiologists in central directorates, epidemiologists or managers of national disease prevention and control programmes and in leadership positions requiring a high degree of analytic capability. Furthermore, graduates were required to commit to 4 years of service to the Ministry of Public Health and Population (8). However, of the 21 Y-FETP graduates, only $28 \%$ are still working in the public health system. The rest are either working in Yemen with international organizations, e.g. WHO (43\%), and national nongovernmental organizations (5\%), outside Yemen as international consultants $(19 \%)$ or doing postgraduate studies (14\%). Departure of Y-FETP graduates from the public health system is usually for better salary or living conditions. Other factors include better working conditions, professional supervision and management, and greater access to education and training opportunities. Therefore, improving public health salaries and working conditions would be useful measures to improve retention. This issue is exacerbated by the war as opportunities for advancement at the Ministry of Public Health and Population have decreased. Nevertheless, it is important to note that
$76 \%$ are still working in Yemen and $48 \%$ are filling positions that were normally filled by international staff. These graduates are better equipped to respond to the current crises in Yemen as they know the country well, are well connected with the communities and can reach difficult or inaccessible areas.

\section{- Sustainability}

- In addition to the current engagement of the residents by the Ministry of Public Health and Population, material and financial resources to support the Y-FETP programme are important indicators for sustainability (24). However, there is limited material support by the Ministry of Public Health and Population (e.g. only office space), and the programme is totally financially dependent on donor support (e.g. TEPHINET, WHO, EMPHNET). Should donor support diminish, the absence of government financial support would have detrimental implications for the sustainability of programme.

\section{- Political instability, war situation and insecurity}

- The Y-FETP started in 2011, the same time as the uprising in Yemen, so it has never operated under normal circumstances. Only the first Y-FETP cohort graduated in 2014 before the current war that broke out in 2015. As result, after 2015, Y-FETP staff and trainees were unable to attend many relevant trainings and conferences outside Yemen due to visa challenges and difficulties in leaving and returning to the country. Therefore, since the conflict started, much of the training has been conducted in Yemen by Yemeni technical experts. Furthermore, due to insecurity, 
three residents from the 2nd cohort fled the capital and were not able to graduate on time. Nevertheless, two of them graduated with the 3rd cohort on 28 February 2018. The programme also managed to enrol the 4th cohort in October 2017.

- Additionally, the current war prevents experts from coming to Yemen for additional technical assistance; this has allowed Yemeni technical professionals to manage the programme.

\section{Conclusion}

The Y-FETP work-based training model proved to be an effective tool for strengthening the capacity of the Yemeni health workforce, especially epidemiologists. This is achieved through field experiences in various settings that were able to improve institutional capacity in a variety of public health areas. The programme focusses on surveillance systems, epidemiologic research, response and containment measures for outbreaks and using data for public health policy- and decision-making. It is providing a practical example of health systems strengthening through health workforce capacity development. The programme has been instrumental in supporting Yemen's health system through the war and the current crisis and emergency situations as the security situation deteriorated and access to outside experts became limited. The residents and the graduates have been extremely valuable in supporting the activities of the Ministry of Public Health and Population. This model can be replicated in countries with similar health workforce capacity challenges, and especially during disasters and emergencies.

Funding: None.

Competing interests: None declared.

\section{Le Programme de formation à l'épidémiologie de terrain au Yémen : un outil de renforcement des capacités des personnels de santé publique \\ Résumé}

Contexte : Dans de nombreux pays à faible revenu, dont le Yémen, la pénurie d'agents de santé publique qualifiés, notamment d'épidémiologistes, demeure un problème important qui entrave la mise en place de systèmes de santé publique efficaces. Afin de pallier ce problème, le ministère de la Santé publique et de la Population a créé le Programme de formation à l'épidémiologie du terrain au Yémen en 2011.

Objectif : Décrire le Programme de formation à l'épidémiologie de terrain du Yémen, ses points forts et ses défis pour répondre aux besoins du système national de santé du Yémen.

Méthodes: Nous décrivons la structure et les fonctions du Programme de formation à l'épidémiologie de terrain du Yémen et analysons les réussites et les obstacles rencontrés au cours des sept premières années de mise en place du programme en examinant leurs rapports avec le système national de santé.

Résultats : Il s'agit d'un programme de formation postuniversitaire axé sur les compétences et visant à renforcer les capacités dans le domaine de l'épidémiologie de terrain, ce qui permettra de détecter des événements de santé publique importants et de les étudier efficacement et en temps utile. Depuis sa création, le Programme a formé avec succès 30 professionnels de santé en épidémiologie de terrain de niveau avancé. De plus, les personnes formées ont examiné plus de 100 flambées épidémiques, analysé et évalué 95 systèmes de surveillance, mené 30 études programmées et effectué 70 exposés oraux et présentations d'affiches lors de conférences nationales et internationales. Les principales difficultés rencontrées sont le faible maintien en poste des diplômés au sein du système national de santé et l'absence de pérennité financière.

Conclusions : Le Programme de formation à l'épidémiologie de terrain a permis de renforcer les capacités des personnels de santé au Yémen et a joué un rôle déterminant en tant que soutien au système national de santé, notamment pendant la guerre, la crise et l'urgence sanitaire actuelles, avec la dégradation de la situation de sécurité et la limitation de l'accès à des experts extérieurs. Ce programme représente un exemple concret de renforcement d'un système de santé grâce au développement des capacités des personnels dans ce secteur et il pourra être reproduit dans d'autres pays présentant des difficultés similaire sur le plan des capacités de leurs personnels de santé.

$$
\text { الخبد الواحد السروري، عائشة جمعان، عبد الحكيم الكحلاني للوبائيات الحقلية: أداة لتعزيز القوى العاملة في الصحة العامة }
$$

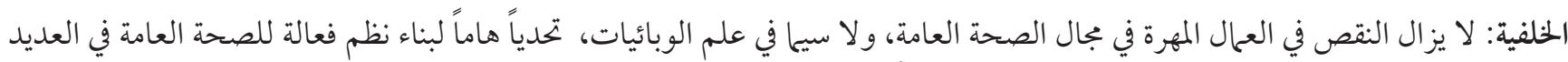

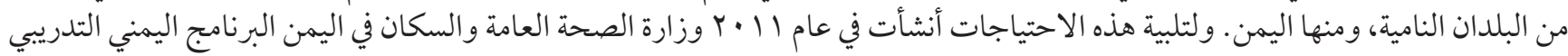


الهدف: وصف البرنامج اليمني التدريبي للوبائيات الحقلية، ونقاط القوة والتحديات التي تواجه تلبية احتياجات النظام الصحي الوطني في اليمن.

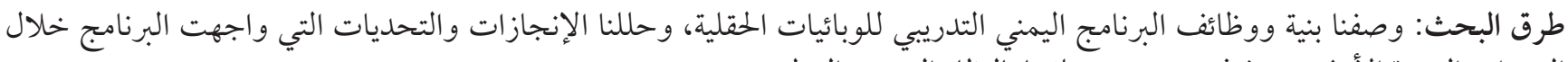

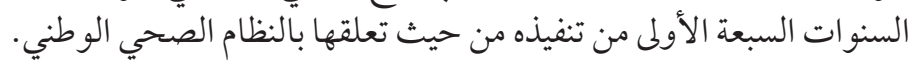

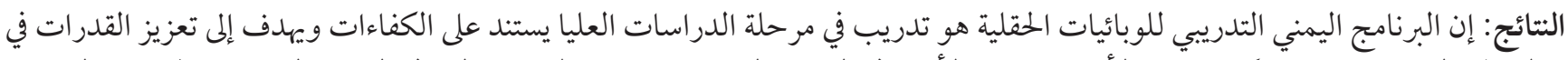

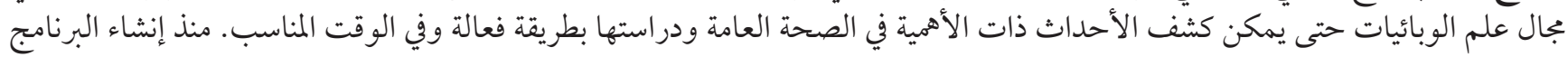

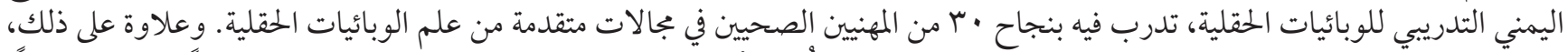

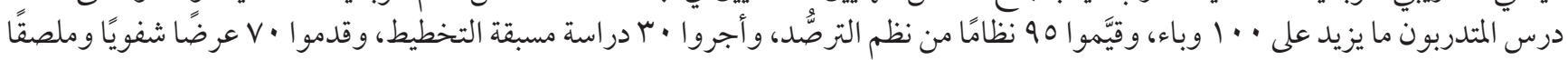

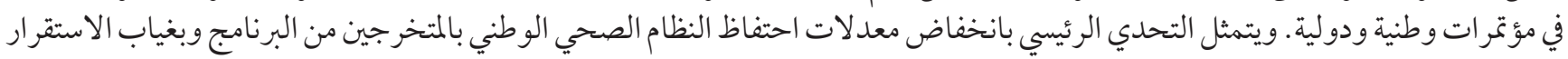

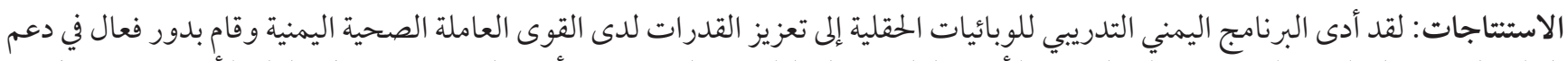

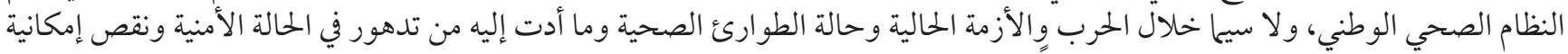

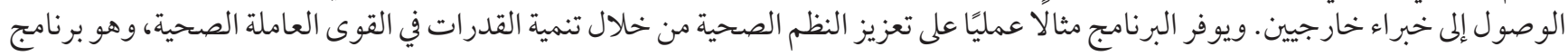

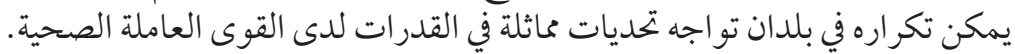

\section{References}

1. Chen L, Evans T, Anand S, Boufford JI, Brown H, Chowdhury M, et al. Human resources for health: overcoming the crisis. Lancet. 2004 Nov 27;364(9449):1984-90. https://doi.org/10.1016/S0140-6736(04)17482-5 PMID:15567015

2. Everybody's business. Strengthening health systems to improve health outcomes. WHO's framework for action. Geneva: World Health Organization; 2007 (http://www.who.int/healthsystems/strategy/everybodys_business.pdf, accessed 9 April 2018)

3. Framework for action for health workforce development in the Eastern Mediterranean Region (2017-2030). Cairo: World Health Organization Regional Office for the Eastern Mediterranean; 2017 (http://www.emro.who.int/images/stories/hrh/Strategic framework_for_health_workforce_development_MAY_2017_3.pdf, accessed 9 April 2018).

4. Health systems profile Yemen. Cairo: World Health Organization Regional Office for the Eastern Mediterranean, Regional Health Systems Observatory; 2006 (http://apps.who.int/medicinedocs/documents/s17314e/s17314e.pdf, accessed 9 April 2018).

5. Country cooperation strategy for WHO and the Republic of Yemen 2008-2013. Cairo: World Health Organization Regional Office for the Eastern Mediterranean; 2010 (WHO-EM/ARD/030/E; http://applications.emro.who.int/docs/CCS_Yemen_2010_EN_14479. pdf, accessed 9 April 2018).

6. Thacker SB, Goodman RA, Dicker RC. Training and service in public health practice, 1951-90-CDC's Epidemic Intelligence Service. Public Health Rep. 1990 Nov-Dec;105(6):599-604. PMID:2175439

7. Field epidemiology training program development handbook. Atlanta, Georgia: Centers for Disease Control and Prevention; 2006.

8. Yemen Field Epidemiology Training Program. Yemen FETP Resident Fieldbook, 2012. Sana'a: Ministry of Public Health and Population, Yemen Field Epidemiology Training Program; 2012 (http://www.yfetp.com/, accessed 1 Sep 2017).

9. Field epidemiology training program: standard core curriculum. Atlanta, Georgia: Centers for Disease Control and Prevention. Coordinating Office for Global Health; 2006 (https://www.cdc.gov/globalhealth/healthprotection/fetp/fetpdevhandbook/curriculum_and_training/cogh_fetp_core_-curriculum_0805.pdf, accessed 1 Sep 2017)

10. Yemen field epidemiology training program. Program guideline. Sana'a: Ministry of Public Health and Population, Yemen Field Epidemiology Training Program; 2015 (http://www.yfetp.com/page.php?id=86, accessed 9 April 2018).

11. Y-FETP newsletter. Issue 6 (April-June 2017). Sana'a: Ministry of Public Health and Population, Yemen Field Epidemiology Training Program; 2017 (http://www.youblisher.com/p/1846975-Y-FETP-Newsletter-Issue-6-April-June-2017/, accessed 9 April 2018).

12. Updated guidelines for evaluating public health surveillance systems. Recommendations from the Guidelines Working Group. Atlanta, Georgia: Centers for Disease Control and Prevention; 2001 (https://www.cdc.gov/mmwr/preview/mmwrhtml/rr5013a1. htm, accessed 9 April 2018).

13. Yemen: cholera outbreak - 2017/2018 - interactive dashboard. Geneva: World Health Organization; 2017 (http://who-powerbi.net/ bi/, accessed 9 April 2018).

14. Al Serouri A, Alkohlani A, Alemad M, Assabri A. The role of field epidemiology in the disasters: Yemen cholera outbreak example. Emerg Med Inves. 2017;EMIG-159. DOI: 10.29011/2475-5605.000059

15. Thabet AAK, Al-Eryani SMA, Aziz NA, Obadi M, Saleh M, Al-Kohlani A, et al. Epidemiological characterization of Chikungunya outbreak in Lahj Governorate, Southern Yemen. J Community Med Health Educ. 2013;3:247. DOI:10.4172/2161-0711.1000247

16. Al Amad M, Al-Eryani L, Al Serouri A, Khader YS. Evaluation of outpatient therapeutic programme (OTP) for treatment of severe acute malnutrition in Yemen: a focus on treatment default and its risk factors. J Eval Clin Pract. 2017 Dec;23(6):1361-6. https://doi. org/10.1111/jep.12798 PMID:28762594 
17. Al-Abhar N, Al-Gunaid EA., Moghram GS, Al-Hababi AA, Al Serouri AW, Khader YS. Knowledge and practice of biosafety among laboratory staff working in clinical laboratories in Yemen. Appl Biosaf. 2017;22(4):168-71

18. Alfalahi E, Assabri A. Pattern of road traffic injuries in Yemen: a hospital-based study. Pan African Med J. 2018;29:145. doi:10.11604/ pamj.2018.29.145.12974

19. Alshahethi, Ahmed; Al Serouri, Abdulwahed; Khader, Yousef Saleh. Rate and pattern of unintentional injuries among 9-12 grades schoolchildren in Yemen and their associated factors. J Inj Violence Res. 2018 Mar 11;10(2). doi: 10.5249/jivr.v10i2.966 PMID:29531184

20. Al-Eryani YM, Nooradain N, Alsharqi K, Murtadha A, Al Serouri A, Khader Y. Unintentional injuries in the three reference laboratories: Sana'a, Yemen. Int J Prev Med. 2017 (ahead of print).

21. Y-FETP. First national Yemen Field Epidemiology Training Program conference, 26-27 February 2014, Sana'a, Yemen ((http:// www.yfetp.com/page.php?cid=4, accessed 15 Sep 2017).

22. Y-FETP. Second national Yemen Field Epidemiology Training Program conference, 29 February 2016, Sana'a, Yemen (http://www. yfetp.com/page.php?cid=23, accessed 15 Sep 2017)

23. Aluwaisheg AA. Yemen's brain drain. The other side of the crisis. Arab News. Monday 19 August 2013 (http://www.arabnews.com/ news/461714, accessed 9 April 2018).

24. Jones D, MacDonald G, Volkov B, Herrera-Guibert D. Multisite evaluation of field epidemiology training programs. Findings and recommendations. Atlanta, Georgia: Centers for Disease Control and Prevention; 2014. 